\title{
Semen Analysis and Insight into Male Infertility
}

\author{
Batool Mutar Mahdi* \\ Department of Microbiology, Consultant Clinical Immunology, Al-Kindy College of Medicine, University of Baghdad, Baghdad, \\ Iraq
}

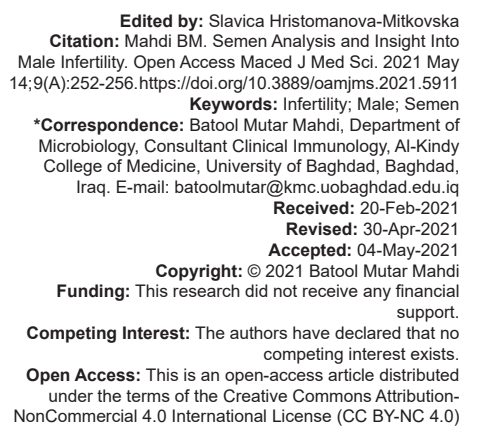

NonCommercial 4.0 International License (CC BY-NC 4.0)

\begin{abstract}
BACKGROUND: Semen analysis is the cornerstone for the valuation of the male partner in infertile couples. This test has been standardized throughout the world through the World Health Organization (WHO) since the1970s by producing, editing, updating, and disseminating a semen analysis manual and guidelines.

AIM: A retrospective semen analysis study that give an insight about male infertility.

METHODS: This retrospective study assessed the semen findings of 1000 men evaluated at the Department of Urology, Al-Kindy Teaching Hospital in Baghdad-Iraq, between January 2016 and May 2019. Semen analysis was done for them.

RESULTS: According to the WHO standard for semen normality, 1000 samples that were analyzed, normospermia was shown in $835(83.5 \%)$ males $(95 \%$ confidence interval $[\mathrm{Cl}]=0.811-0.857)$ and $12 \%$ had oligospermia and the rest $4.5 \%$ was azoospermia. The normospermic samples had significantly higher levels regarding the following parameters: Count per $\mathrm{ml}(51.30 \pm 1.24)(p=0.001)$, volume $(3.34 \pm 2.31)(p=0.0001)$, pus cell $(8.04 \pm 1.02)$ $(p=0.0001)$, motility $(22.81 \pm 5.8)(p=0.0001)$, abnormal motility $(22.81 \pm 5.8)(p=0.0001)$, and normal $(V)$ $(p=0.0001)$ or abnormal morphology $(25.86 \pm 12.4)(p=0.0002)$ when compared with oligospermia.

CONCLUSIONS: Semen analysis is the keystone of infertile couple. Semen parameters such as sperm concentration, motility, and morphology are indicators for male reproductive function. Sperm concentration is declining and there is a significant association between sperm concentration and sperm parameters.
\end{abstract}

\section{Introduction}

Infertility is a global health problem in the community with physical, psychological, and social influences. Infertility can be defined as a failure in achieving a successful pregnancy of a couple after 12 months or 1 year of regular sexual intercourse without using protection or contraceptive methods [1]. It represents about $10-15 \%$ of couples that are seen in clinical daily practice and constitutes about 40-50\% of the 70 million cases worldwide and caused by malefactors and from each infertile six couples, one of them either husband or wife experiences primary or secondary infertility [2]. According to the records from the World Health Organization (WHO), about 40\% of infertility cases are due to male factors which are due to aging processes that lead to decrease sperm motility, sedentary work, and lack of exercise [3]. Other factors are infection and oxidative stress and an increase in inflammatory cytokines in seminal plasma that decreases sperm quality and damage sperm DNA [4], [5]. Nutritional factor had an important role in sexual health and semen quality, especially Vitamin D deficiency [6]. Semen or sperm analysis after 3 days of abstinence is usually the first laboratory test that done and one of the most important test for fertility tracking and follow-up. Meanwhile, this test has to be conducted in the laboratory, many men patients are unwilling to be tested for this simple test as a result of social stigma and embarrassment in certain regions of the world. The characteristics of male infertility are an abnormality in sperm motility, $\mathrm{PH}$, color, morphology, velocity, semen volume, sperm concentration, and sperm count that done using visual examination, microscope, and counting chambers [7]. This method is complex, laborintensive, subjective, and liable to human error, so another method was used which is computer-assisted semen analysis which is effective in tracking sperm and many laboratories do not follow the instructions and guidelines of the WHO in doing semen analysis and do not follow the recommended methods in the test [8]. Hence, this study tries to shed light on the frequency of male factor infertility in the last 10 years.

\section{Patients and Methods}

This retrospective study assessed the semen findings of 1000 men evaluated at the Department of Urology, Al-Kindy Teaching Hospital in Baghdad-Iraq 
between January 2016 and May 2019 and was referred for semen analysis to the laboratory as part of male infertility investigation and venereal infection. History was taken from them regarding age, duration of marriage, first or second marriage, occupation, type of infertility, whether primary or secondary, drug intake, symptoms of any venereal infection, surgical, and medical history. Males excluded from the study were those who received treatment such as antioxidants therapy, surgical treatment such as varicocelectomy and seminal tract reconstruction; patients were unable to pass specimen by masturbation.

The study protocol was reviewed by the Scientific and Ethical Committee of Al-Kindy Medical College without funding.

Patients were instructed to give a sample after abstinence from coitus for 3-4 days and collected aseptically by masturbation into sterile wide-mouthed containers within hospital. Semen analysis was performed according to the methods and standards outlined by the WHO [9]. The parameters included the following: Appearance (grey to opalescent); volume (2.0 $\mathrm{ml}$ or more); $\mathrm{PH}$ (7.2-7.8); sperm concentration (>15 $\times 10^{6}$ spermatozoa/ml); total sperm count $\left(39 \times 10^{6}\right.$ or more/ejaculate); motility $(50 \%$ or more with forward progression); morphology (4\% or more with normal form); and white cell count or pus cell $\left(<1 \times 10^{6} / \mathrm{ml}\right)$.

The semen analysis was done within 60 min after collection, then after liquefaction, the semen specimen was thoroughly mixed with the help of a pipette for the following parameters: Volume was measured with a graduated disposable pipette, appearance, $\mathrm{pH}$ was estimated with $\mathrm{pH}$ paper, liquefaction, concentration, motility, morphology, and viability and the presence of pus cells was assessed by microscope.

Semen samples were divided on the basis of sperm count per milliliter of semen in accordance with the WHO: Normospermia, oligospermia, and azoospermia. The samples grouped were compared for ejaculated volume, pus cells, motility, and morphology. The following definitions were used according to the WHO definitions: Normospermia: Sperm count $15 \mathrm{million} / \mathrm{ml}$ to $120 \mathrm{million} / \mathrm{ml}$., oligospermia: Sperm count below 15 million $/ \mathrm{ml}$., azoospermia: Absence of spermatozoa in the ejaculation, asthenospermia: Reduced sperm motility, teratozoospermia: Abnormal sperm morphology, oligoasthenoteratospermia: All sperm variables abnormal, hypospermia: Volume $<2 \mathrm{ml}$., and Hyperspermia: Volume $>5 \mathrm{ml}$.

The study was registered in clinical trail.gov with NCT04178954 and link was (https://register.clinicaltrials. gov/prs/app/template/Home.vm?uid=U0004R9N\& ts $=45 \& c x=f v i a 6 f, h t t p s: / / r e g i s t e r$.clinicaltrials.gov/ prs/app/action/ReleaseProtocol?uid=U0004R9N\&ts $=37 \&$ sid=S0009ERV\&cx=cfbgkt, https://register. clinical trials. gov/prs/app/action/ViewOrUnrelease? uid=U0004R9N \&ts=43\&sid=S000 9ERV\&cx=gjr3ax.
The work has been reported in line with the STROCSS criteria [10].

\section{Statistical analysis}

The data were analyzed using Minitab version 3.0 software. Frequencies were determined by direct counting. Mean \pm standard deviation was estimated for sperm count, volume, pus cells, motility, and morphology; 95\% confidence interval $(\mathrm{Cl})$ was calculated for proportions and for means. Mean values were compared for statistical significance using Student's t-test. The value with the level of significance was $(p<0.05)$.

\section{Results}

The study includes 1000 male patients, their age ranged from 15 to 60 years with mean age were $(32 \pm 1.43)$. The highest age frequency was between 31 and 40 years $(39.5 \%)$, with $95 \% \mathrm{Cl}$ was $0.365-0.426$. Mean ejaculation abstinence time was $3 \pm 0.26$, as shown in Table 1.

Table 1: Main characteristics of the study population

\begin{tabular}{llll}
\hline Characteristics & Frequency No. $=1000$ & Percentage & $95 \%$ Confidence interval \\
\hline Mean age (ys) X \pm SD & $32 \pm 1.43$ & --- & $31.911-32.088$ \\
Age 15-20 Ys. & 46 & 4.6 & $0.034-0.061$ \\
Age 21-30 Ys. & 287 & 28.7 & $0.259-0.316$ \\
Age 31-40 Ys. & 395 & 39.5 & $0.365-0.426$ \\
Age 41-50 Ys. & 194 & 19.4 & $0.170-0.220$ \\
Age 51-60 Ys. & 78 & 7.8 & $0.062-0.096$ \\
Mean ejaculation abstinence & $3 \pm 0.26$ & --- & $2.983-3.016$ \\
time (ds.) X \pm SD & & & \\
\hline
\end{tabular}
time (ds.) $X \pm S D$

According to the WHO standard for semen normality, 1000 samples that were analyzed, normospermia was shown in 835 (83.5\%)males (95\% $\mathrm{Cl}=0.811-0.857)$ and $12 \%$ had oligospermia and the rest $4.5 \%$ was azoospermia as demonstrated in Table 2. Table 3 revealed the distribution of semen volume, $74 \%$ of total sample study had normospermia $(2-5 \mathrm{ml})$ and $24.5 \%$ had hypospermia $(<2 \mathrm{ml})$ and the rest $(1.5 \%)$ was hyperspermia $(>5 \mathrm{ml})$. Other semen parameters were compared in oligospermic and normospermic samples for count per ml, volume, pus cell, motility, and normal or abnormal morphology. The normospermic samples had significantly higher levels regarding the following parameters (Table 4): Count per $\mathrm{ml}(51.30 \pm 1.24)(p=0.001)$, volume $(3.34 \pm$ $2.31)(p=0.0001)$, pus cell $(8.04 \pm 1.02)(p=0.0001)$, motility $(22.81 \pm 5.8)(p=0.0001)$, abnormal motility $(22.81 \pm 5.8)(p=0.0001)$, and normal $(V)(p=0.0001)$ or abnormal morphology $(25.86 \pm 12.4)(p=0.0002)$ when compared with oligospermia. Other semen abnormalities was shown in Table 5 like asthenospermia that presents in $13 \%$ of the total samples with $95 \%$ $\mathrm{Cl}=0.109-0.151$, teratospermia (11.1\%) $(95 \%$ $\mathrm{Cl}=0.092-0.13)$, oligoasthenoteratospermia $(4.5 \%)$ 
(95\% Cl $=0.032-0.058)$, and agglutination present in $3.6 \%$ of the patients $(95 \% \mathrm{Cl}=0.024-0.048)$.

Table 2: Frequency of sperm concentration/ml

\begin{tabular}{llll}
\hline Group & Frequency No=1000 & Percentage & $95 \%$ Confidence interval \\
\hline Normospermia & 835 & 83.5 & $0.811-0.857$ \\
Oligospermia & 120 & 12.0 & $0.100-0.142$ \\
Azoospermia & 045 & 4.5 & $0.032-0.058$ \\
\hline
\end{tabular}

Table 3: Distribution of seminal volume

\begin{tabular}{llll}
\hline Volume & Frequency No=1000 & Percentage & $95 \%$ Confidence interval \\
\hline Normospermia $(2-5 \mathrm{ml})$ & 740 & 74.0 & $0.712-0.767$ \\
Hypospermia $(<2 \mathrm{ml})$ & 245 & 24.5 & $0.219-0.273$ \\
Hyperspermia $(>5 \mathrm{ml})$ & 15 & 1.5 & $0.008-0.025$ \\
\hline
\end{tabular}

\section{Discussion}

Semen quality is an important factor in determining infertility and females remain a target of society for this dilemma and there are many risk factors for female infertility such as previous CS, menstrual cycle disturbance, regular daily caffeine intake, and obesity [11]. In addition to that, researches proved that males have equal contribution to this problem. Male infertility is the inability to cause pregnancy in a fertile female and constitutes about $40-50 \%$ of infertility [12]. Causes of male infertility can be divided into pretesticular, testicular, and post-testicular. Semen quality is a surrogate measure of male productiveness and defining thresholds for normal ranges is so difficult and sperm count is declining in the world. Thus, screening of males by simple semen analysis test gives an idea about the pathological infertility problems. This study showed the frequency of normospermia $(83.5 \%)$, oligospermia (12\%), and azoospermia (4.5\%) in male infertile subjects and the distribution of other abnormal semen parameters was hypospermia $(<2 \mathrm{ml})(24.5 \%)$, hyperspermia $(>5 \mathrm{ml})(1.5 \%)$, asthenospermia $(13 \%)$, and teratospermia $(11.1 \%)$. There were a significant difference $(p=0.0001)$ between normospermic count per $\mathrm{ml}$ (51.30 \pm 1.24$)$, volume $(3.34 \pm 2.31)(p=0.0001)$, pus cell $(8.04 \pm$ 1.02) $(p=0.0001)$, motility $(22.81 \pm 5.8)(p=0.0001)$, abnormal motility $(22.81 \pm 5.8)(p=0.0001)$, and normal (V) $(p=0.0001)$ or abnormal morphology $(25.86 \pm 12.4)$ $(p=0.0002)$ when compared with oligospermia. This indicates that there was an association between sperm count and abnormalities in other parameters. Another study done by Butt and Akram, 2013, showed that mean sperm count was $135.41 \pm 70.6$ in normospermia, another study in the UK showed mean sperm count was $84.3 \pm 78.3 .7$, while other research demonstrated that sperm count was $86.8+7.5 \mathrm{million} / \mathrm{ml}$ [13], [14], [15]
These differences with our study may be due to sample size, method use in semen study such as home-based semen analysis and swim-up technique for sperm preparation that is increased motility and decreased DNA damage [16], [17], time of the study because sperm count and quality is declining in $21^{\text {st }}$ century because of some associations with chemical exposures leading to endocrine disruption [18] and geographical differences [19]. This study was in accordance with a meta-analysis study that showed sperm density has decreased all over the world around $50 \%$ over the last 60 years leading to more attraction and controversy [20].

Azoospermia affects about $4.5 \%$ of the study male population and may be due to sperm production or transport, while oligospermia about 12\%. Another study showed that the prevalence of azoospermia was $14.28 \%$ and oligospermia was $21.43 \%$ [21] while in another study was 33\% [22]. Thus, there were controversies between the results which may be due to sample size.

Regarding the ejaculated volume, about $24.5 \%$ showed hypospermia, while other studies showed hypospermia was $10.3 \%, 9 \%$ [23], [24]. This may be due to associated abnormalities in accessory sex glands fluid synthesis such as seminal vesical, defect in the transport such as physical obstruction in the genital tract, retrograde ejaculation, or duration of abstinence.

According to sperm motility in this study was $22.81 \pm 5.8$ in normospermia and asthenospermia was $13 \%$ which is important in sperm travel a long very long distance to reach oocyte. Good motility occurs from sperm maturation in their way through the epididymis, which is under the effect of epididymal proteins. Hence, motility is an indicator of post-testicular epididymal function [25]. Cigarette smoking had an association with decreased sperm count, motility, and semen quality which is more marked in moderate and heavy smokers because toxins from tobacco can affect sperm development and function [26]. Other studies showed asthenospermia was in $25 \%, 21.42 \%$, and $18 \%$ [13], [27], [28].

Morphology of the sperm is another important such as two heads or two tails and other abnormal shapes which is the function of testes and epididymis. In this study, mean normal morphology in normospermia samples was $74.13 \pm 8.64$, while in oligospermic samples were $28.5 \pm 11.8(p=0.0001)$. This was in opposing with another study that showed abnormal morphology was 53\% and abnormal motility in $60 \%$ oligospermic males. This because of sperm motility

Table 4: Comparisons of semen parameters between normospermia and oligospermia

\begin{tabular}{|c|c|c|c|c|c|c|c|}
\hline Group & Count/mlX \pm SD & Volume $\mathrm{X} \pm \mathrm{SD}$ & Pus cell $X \pm S D$ & $\begin{array}{l}\text { Motile sperms }(A) \text { rapid } \\
\text { progressive } X \pm S D\end{array}$ & $\begin{array}{l}\text { Non motile sperms } \\
\text { (D) } X \pm S D\end{array}$ & Normal sperms $\mathrm{X} \pm \mathrm{SD}$ & Abnormal sperms $\mathrm{X} \pm \mathrm{SD}$ \\
\hline Normospermia No. $=853$ & $51.30 \pm 1.24$ & $3.34 \pm 2.31$ & $8.04 \pm 1.02$ & $22.81 \pm 5.8$ & $38.26 \pm 9.57$ & $74.13 \pm 8.64$ & $25.86 \pm 12.4$ \\
\hline $95 \%$ Confidence interval & $51.21667-51.38333$ & $3.18476-3.49524$ & $7.97145-8.10855$ & $22.42022-23.19978$ & $37.61686-38.90314$ & 73.54936-74.71064 & $25.02668-26.69332$ \\
\hline Oligospermia No. $=120$ & $7.08 \pm 3.18$ & $0.8 \pm 0.15$ & $6.66 \pm 0.5$ & $8 \pm 1.51$ & $34.1 \pm 5.72$ & $28.5 \pm 11.8$ & $21.5 \pm 7.5$ \\
\hline $95 \%$ Confidence interval & $6.50519-7.65481$ & $0.77289-0.82711$ & $6.56962-6.75038$ & $7.72706-8.27294$ & $33.06607-35.13393$ & $26.36706-30.63294$ & $20.14432-22.85568$ \\
\hline${ }^{*} \mathrm{p}$-value & 0.0001 & 0.0001 & 0.0001 & 0.0001 & 0.0001 & 0.0001 & 0.0002 \\
\hline
\end{tabular}

*Student's t-test. SD: Standard deviation. 
and morphology are changing parameters and their levels depend on the sperm count in an individual [29]. In addition to that, some laboratories do not follow the orders of the $\mathrm{WHO}$ in performing semen analysis, and most of them do not do the instruction and methods in doing the test [8]. Other affecting factors are a decrease in the level of Vitamin D and physical exercise [30].

\section{Table 5: Proportions of other semen abnormalities}

\begin{tabular}{llll}
\hline Abnormal parameters & Frequency & Percentage & $95 \%$ Confidence interval \\
\hline Asthenospermia & 130 & 13 & $0.109-0.151$ \\
Teratospermia & 111 & 11.1 & $0.092-0.13$ \\
Oligoasthenoteratospermia & 45 & 4.5 & $0.032-0.058$ \\
Presence of pus cell & 168 & 16.8 & $0.145-0.191$ \\
Presence of agglutination & 36 & 3.6 & $0.024-0.048$ \\
\hline
\end{tabular}

Infection of the male genital tract, presence of pus cells, and agglutination of the sperms is important morbidity factors. It may affect seminal quality through a direct action on spermatozoa or their environment.

\section{Conclusions}

Semen analysis is the keystone of the infertile couple. Semen parameters such as sperm concentration, motility, and morphology are indicators for male reproductive function. Sperm concentration in our country is declining as in other parts of world and there is a significant association between sperm concentration and sperm parameters.

\section{References}

1. Patel AS, Leong JY, Ramasamy R. Prediction of male infertility by the World Health Organization laboratory manual for assessment of semen analysis: A systematic review. Arab J Urol. 2017;16(1):96-102. https://doi.org/10.1016/j.aju.2017.10.005 PMid:29713540

2. Morin SJ, Scott RT. Knowledge gaps in male infertility: A reproductive endocrinology and infertility perspective. Transl Androl Urol. 2018;7(Suppl 3):S283-91. https://doi.org/10.21037/ tau.2018.05.02

PMid:30159234

3. Harmoosh SK, Almadfaiee ZA. Estimation of the seminal fluid of subfertile patients of different age groups. J Facult Med Baghdad._2011;53:428-31.

4. Seshadri S, Bates M, Vince G, Jones DI. The role of cytokine expression in different subgroups of subfertile men. Am J Reprod Immunol. 2009;62(5):275-82. https://doi. org/10.1111/j.1600-0897.2009.00736.x

5. Lazem A, Al-Kaseer E, Al-Diwan J, Al-Hadithi T. Effect of infection on semen parameters in a sample of Iraqi infertile males. J Fac Med Bagdad. 2010;52:274-6.

6. Arab A, Hadi A, Moosavian SP, Askari G, Nasirian M. The association between serum Vitamin $D$, fertility and semen quality: A systematic review and meta-analysis. Int J Surg. 2019;71:101-9. https://doi.org/10.1016/j.jjsu.2019.09.025 PMid:31561004
7. Tocci A, Lucchini C. WHO reference values for human semen. Hum Reprod Update. 2010;16(5):559. https://doi.org/10.1093/ humupd/dmq019

PMid:20542895

8. Ahadi M, Aliakbari F, Latifi S, Hosseini SJ, Gharib A, Movafagh A, et al. Evaluation of the standardization in semen analysis performance according to the $\mathrm{WHO}$ protocols among laboratories in Tehran, Iran. Iran J Pathol. 2019;14(2):142-7. https://doi.org/10.30699/ijp.14.2.142

\section{PMid:31528171}

9. Cooper TG, Noonan E, von Eckardstein S, Auger J, Baker HW Behre HM, et al. World Health Organization reference values for human semen characteristics. Hum Reprod Update. 2010;16(3):231-45. https://doi.org/10.1093/humupd/dmp048 PMid: 19934213

10. Agha RA, Borrelli MR, Vella-Baldacchino M, Thavayogan R, Orgill DP; STROCSS Group. The STROCSS statement: Strengthening the reporting of cohort studies in surgery. Int J Surg. 2017;46:198-202. https://doi.org/10.1016/j. isjp.2017.08.001 PMid:28890409

11. Ajeel NA, Abdul-Kader RA. Female infertility: A study of risk factors. J Facult Med Baghdad. 2014;56:200-4

12. Brugh VM, Lipshultz LI. Male factor infertility. Med Clin North Am. 2004;88(2):367-85.

PMid:15049583

13. Butt F, Akram N. Semen analysis parameters: Experiences and insight into male infertility at a tertiary care hospital in Punjab. $J$ Pak Med Assoc. 2013;63(5):558-62.

PMid:23757979

14. Mortimer D, Templeton AA, Lenton EA, Coleman RA. Semen analysis parameters and their interrelationships in suspected infertile men. Arch Androl. 1982;8(3):165-71. https://doi. org/10.3109/01485018208987035 PMid:7103595

15. Shoaib KM, Irshad A, Musa KB, Faheem T. Evaluation of the gonadotropic ratios among men with varying sperm quality. Pak J Med Res 2005;44:19-22.

16. YuS, RubinM, GeevarugheseS, PinoJS, RodriguezHF,AsgharW Emerging technologies for home-based semen analysis. Andrology. 2018;6(1):10-9. https://doi.org/10.1111/andr.12441 PMid:29194998

17. AL-Marayaty SS, Saeed GT, AL-Ahmed HI. Effect of swim up techniques on sperm motility and DNA integrity versus unprepared semen. J Fac Med Baghdad 2017;59(2):151-5. https://doi.org/10.32007/med.1936/jfacmedbagdad.v59i2.10

18. Virtanen HE, Jørgensen N, Toppari J. Semen quality in the $21^{\text {st }}$ century. Nat Rev Urol. 2017;14(2):120-30. https://doi. org/10.1038/nrurol.2016.261

PMid:28050014

19. Elbardisi H, Majzoub A, Al Said S, Al Rumaihi K, El Ansari W, Alattar A, et al. Geographical differences in semen characteristics of 13892 infertile men. Arab J Urol 2018;16(1):3-9. https://doi. org/10.1016/j.aju.2017.11.018 PMid:29713531

20. Harry F. Declining worldwide sperm counts: Disproving a myth Urol Clin N Am. 2008;35:137-46. PMid:18423235

21. Khan DA, Khan FA, Sattar A, Naveed AK, Malik IA. Azoospermia in clinical practice at Rawalpindi. Pak Armed Forces Med J. 1992;42:93-5.

22. Subhan F, Tahir F, Ahmed R, Khan ZU. Oligospermia and its relation with hormonal profile. J Pak Med Assoc. 1995;45(9):246-7 . 
PMid:8683833

23. Imam ME, Siuf A, Mansour MM, Khalid KE, Yosif N, Elhasan EM, et al. Semen analysis of infertile Sudanese males in Gezira State, Central Sudan. Sudan J Public Health 2009;4:340-4.

24. Nwafia WC, Igweh JC, Udebuani IN. Semen analysis of infertile Igbo males in Enugu, Eastern Nigeria. Niger J Physiol Sci 2006;21(1-2):67-70. https://doi.org/10.4314/njps.v21i1-2.54254 PMid:17242721

25. Akhtar MS, Akhtar FK. Causes of male infertility. Pak J Med Res. 1991;30:159-62.

26. Sharma R, Agarwal A, Esteves SC. Cigarette smoking and semen quality: A new meta-analysis examining the effect of the 2010 World Health Organization laboratory methods for the examination of human semen. Eur Urol. 2016;70(4):635-45. https://doi.org/10.1016/j.eururo.2016.05.051

PMid:27113031

27. Subhan F, Tahir, F, Alam W, Sultan S, Shahab M. Seminal and hormonal profiles of fertile and subfertile Pakistani men a study of infertility cases. Pak J Med Res. 2000;39:42-5.

28. Curi SM, Ariagno JI, Chenlo PH, Mendeluk GR, Pugliese MN Sardisegovia LM, et al. Asthenozoospermia: Analysis of a large population. Arch Androl 2003;49:343-9. https://doi. org/10.1080/713828220

PMid: 12893510

29. Dua AA, Vaidya SR. Sperm motility and morphology as changing parameters linked to sperm count variations. J Postgrad Med. 1996;42(4):93-6

PMid:9715307

30. Yan X, Dong L, Liu Y, Yang F, Tan K, Li J, et al. Effects of physical exercises on semen quality and reproductive outcomes in male infertility: A protocol for systematic review and meta-analysis of randomized controlled trials. Medicine (Baltimore). 2019;98(41):e17494. https://doi.org/10.1097/ md.0000000000017494

PMid:31593115 